Christian Fuchs and Vincent Mosco, eds. 2012. Marx is Back The Importance of Marxist Theory and Research for Critical Communication Studies Today.

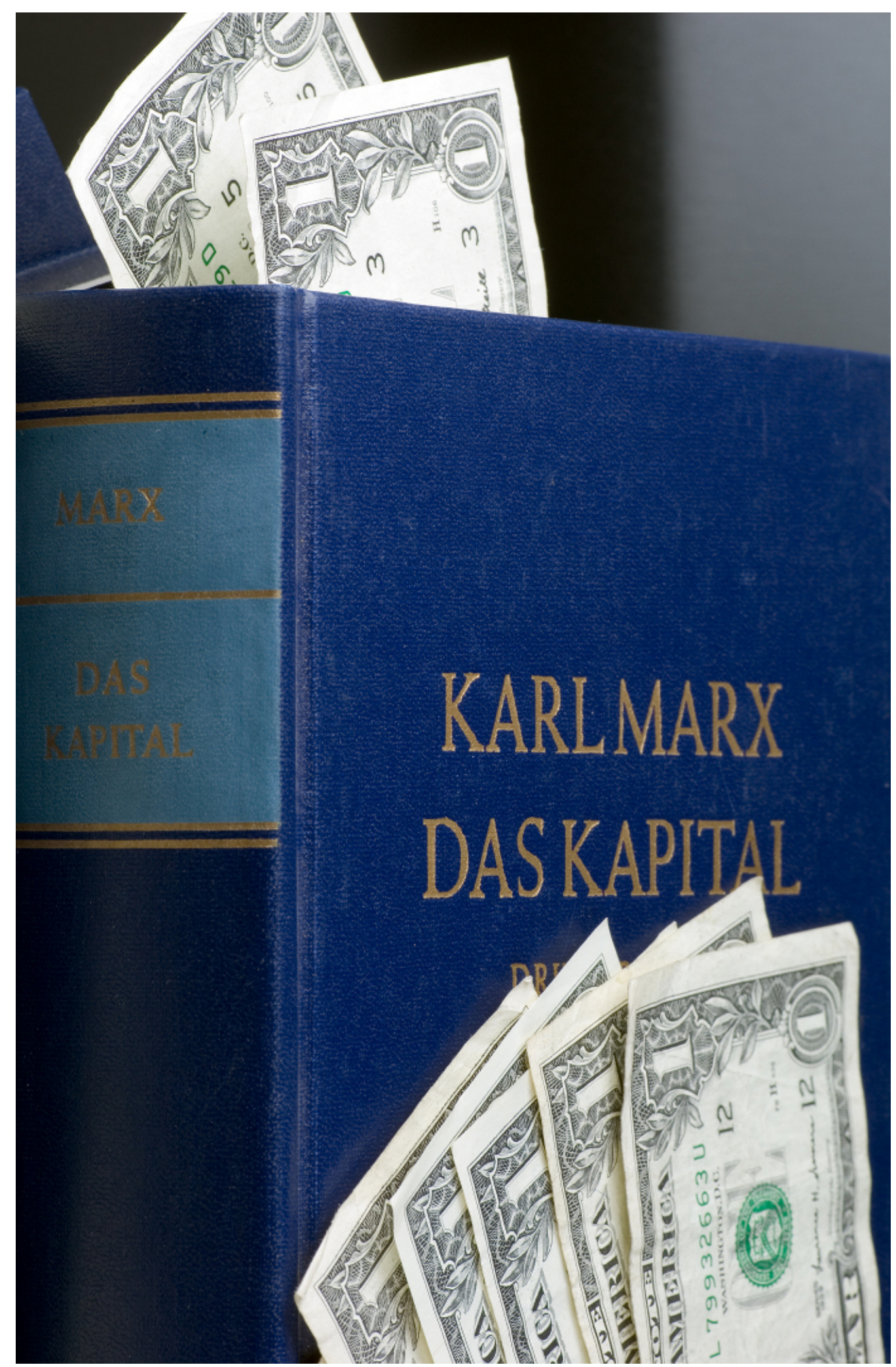

tripleC - Open Access Journal for a Global Sustainable Information Society (http://www.triple-c.at) 10 (2): 127-632. 

Title image: U. Buman: Dollar - Das Kapital, http://www.digitalstock.de

\section{Contents}

127-140 Christian Fuchs and Vincent Mosco

Introduction: Marx is Back - The Importance of Marxist Theory and Research for Critical Communication Studies Today.

\section{Marx, the Media, Commodities, and Capital Accumulation}

141-155 Nicole S. Cohen

Cultural Work as a Site of Struggle: Freelancers and Exploitation

156-170 Mattias Ekman

Understanding Accumulation: The Relevance of Marx's Theory of Primitive Accumulation in Media and Communication Studies

171-183 Eran Fisher

How Less Alienation Creates More Exploitation? Audience Labour on Social Network Sites

184-202 Richard Hall and Bernd Stahl

Against Commodification: The University, Cognitive Capitalism and Emergent Technologies

203-213 William Henning James Hebblewhite

"Means of Communication as Means of Production" Revisited

214-229 Vincent Manzerolle and Atle Mikkola Kjøsen

The Communication of Capital: Digital Media and the Logic of Acceleration

230-252 George Pleios

Communication and Symbolic Capitalism. Rethinking Marxist Communication Theory in the Light of the Information Society

253-273 Robert Prey

The Network's Blindspot: Exclusion, Exploitation and Marx's Process-Relational Ontology

274-301 Jernej Prodnik

A Note on the Ongoing Process of Commodification: From the Audience

Commodity to the Social Factory

302-312 Jens Schröter

The Internet and "Frictionless Capitalism" 


\section{3-333 Andreas Wittel}

Digital Marx: Toward a Political Economy of Distributed Media

\section{Marx and Ideology Critique}

334-348 Pablo Castagno

Marxist Theory in Critical Transitions: The Democratization of the Media in PostNeoliberal Argentina

349-391 Irfan Erdogan

Missing Marx: The Place of Marx in Current Communication Research and the Place of Communication in Marx's Work

392-412 Christian Fuchs

Towards Marxian Internet Studies

413-424 Christian Garland and Stephen Harper

Did Somebody Say Neoliberalism?: On the Uses and Limitations of a Critical Concept in Media and Communication Studies

425-438 Jim McGuigan

The Coolness of Capitalism Today

439-456 Brice Nixon

Dialectical Method and the Critical Political Economy of Culture

457-473 Michelle Rodino-Colocino

"Feminism" as Ideology: Sarah Palin's Anti-feminist Feminism and Ideology

Critique

474-487 Gerald Sussman

Systemic Propaganda as Ideology and Productive Exchange

\section{Marx and Media Use}

488-508 Brian A. Brown and Anabel Quan-Haase

"A Workers' Inquiry 2.0": An Ethnographic Method for the Study of Produsage in Social Media Contexts

509-517 Katarina Giritli Nygren and Katarina L Gidlund

The Pastoral Power of Technology. Rethinking Alienation in Digital Culture

\section{Marx, Alternative/Socialist Media and Social Struggles}

518-536 Miriyam Aouragh

Social Media, Mediation and the Arab Revolutions

537-554 Lee Artz

$21^{\text {st }}$ Century Socialism: Making a State for Revolution 
555-569 Peter Ludes

Updating Marx's Concept of Alternatives

570-576 Vincent Mosco

Marx is Back, But Which One? On Knowledge Labour and Media Practice

577-599 Wilhelm Peekhaus

The Enclosure and Alienation of Academic Publishing: Lessons for the Professoriate

600-617 Sebastian Sevignani

The Problem of Privacy in Capitalism and the Alternative Social Networking Site Diaspora*

618-632 Padmaja Shaw

Marx as Journalist: Revisiting the Free Speech Debate 


\title{
Introduction: Marx is Back - The Importance of Marxist Theory and Research for Critical Communication Studies Today Christian Fuchs and Vincent Mosco
}

\author{
Uppsala University, Uppsala, Sweden, christian.fuchs@im.uu.se \\ Queen’s University, Kingston, Canada, moscov@mac.com
}

\begin{abstract}
This paper introduces the overall framework for tripleC's special issue "Marx is Back. The Importance of Marxist Theory and Research for Critical Communication Studies Today". We point out why there is a return of the interest in Marx ("Marx is back") and why Marxian analysis is important for Critical Communication Studies today. We also provide a classification of Marxian dimensions of the critical analysis of media and communication and discuss why commonly held prejudices against what Marx said about society, media, and communication are wrong. The special issue shows the importance of Marxist theory and research for Critical Communication Studies today.
\end{abstract}

Keywords: Marx, Marxism, Marxist political economy of media and communication, critical communication studies, critical media studies, critical theory.

* "Marx is fashionable again,' declares Jorn Schutrumpf, head of the Berlin publishing house Dietz, which brings out the works of Marx and his collaborator Friedrich Engels. Sales have trebled - albeit from a pretty low level - since 2005 and have soared since the summer. [...] The Archbishop of Canterbury, Rowan Williams, gave him a decent review last month: 'Marx long ago observed the way in which unbridled capitalism became a kind of mythology, ascribing reality, power and agency to things that had no life in themselves.' Even the Pope has put in a good word for the old atheist praising his 'great analytical skill'". (The Times, Financial crisis gives added capital to Marx's writings. October 20, 2008)

* "No one claims that we're all Marxists now but I do think the old boy deserves some credit for noticing that 'it's the economy, stupid' and that many of the apparently omniscient titans who ascend the commanding heights of the economy are not so much stupid as downright imbecilic, driven by a mad exploitative greed that threatens us all. Marx's work is not holy writ, despite the strivings of some disciples to present it as such" (The Evening Standard, Was Marx Right All Along?. March 30, 2009).

* "Karl Marx is back. That, at least, is the verdict of publishers and bookshops in Germany who say that his works are flying off the shelves" (The Guardian, Booklovers Turn to Karl Marx as Financial Crisis Bites in Germany. October 15, 2008).

* "Policy makers struggling to understand the barrage of financial panics, protests and other ills afflicting the world would do well to study the works of a long-dead economist: Karl Marx. The sooner they recognize we're facing a once-in-a-lifetime crisis of capitalism, the better equipped they will be to manage a way out of it" (Bloomberg Business Week, Give Karl Marx a Chance to Save the World Economy. August 28, 2011).

* Time Magazine showed Marx on its cover on February $2^{\text {nd }}, 2009$, and asked in respect to the crisis: "What would Marx think?" In the cover story, Marx was presented as the saviour of capitalism and was thereby mutilated beyond recognition: "Rethinking Marx. As we work out how to save capitalism, it's worth studying the system's greatest critic" (Time Magazine Europe, February $2^{\text {nd }}$, 2009).

These news clippings indicate that with the new global crisis of capitalism, we seem to have entered new Marxian times. That there is suddenly a surging interest in Karl Marx's work is an indication for the persistence of capitalism, class conflicts, and crisis. At the same time, the bourgeois press tries to limit Marx and to stifle his theory by interpreting Marx as the new saviour of capitalism. One should remember that he was not only a brilliant analyst of capitalism, he was also the strongest critic of capitalism in his time: "In short, the Communists everywhere support every revolutionary movement against the existing social and political order of things. In all these movements, 
they bring to the front, as the leading question in each, the property question, no matter what its degree of development at the time. Finally, they labour everywhere for the union and agreement of the democratic parties of all countries. The Communists disdain to conceal their views and aims. They openly declare that their ends can be attained only by the forcible overthrow of all existing social conditions. Let the ruling classes tremble at a Communistic revolution. The proletarians have nothing to lose but their chains. They have a world to win. Proletarians of all lands unite!" (Marx and Engels 1848/2004, 94).

In 1977, Dallas Smythe published his seminal article Communications: Blindspot of Western Marxism (Smythe 1977), in which he argued that Western Marxism had not given enough attention to the complex role of communications in capitalism. 35 years have passed and the rise of neoliberalism resulted in a turn away from an interest in social class and capitalism. Instead, it became fashionable to speak of globalization, postmodernism, and, with the fall of Communism, even the end of history. In essence, Marxism became the blindspot of all social science. Marxist academics were marginalized and it was increasingly career threatening for a young academic to take an explicitly Marxist approach to social analysis.

The declining interest in Marx and Marxism is visualized in Figure 1 showing the number of articles in the Social Sciences Citation Index that contain one of the keywords Marx, Marxist, or Marxism in the article topic description and were published in the five time periods 1968-1977, 19781987, 1988-1997, 1998-2007, 2008-2011. Choosing these periods allows one to determine if there has been a change since the start of the new capitalist crisis in 2008 and also makes sense because social upheavals in 1968 marked a break that also transformed academia.

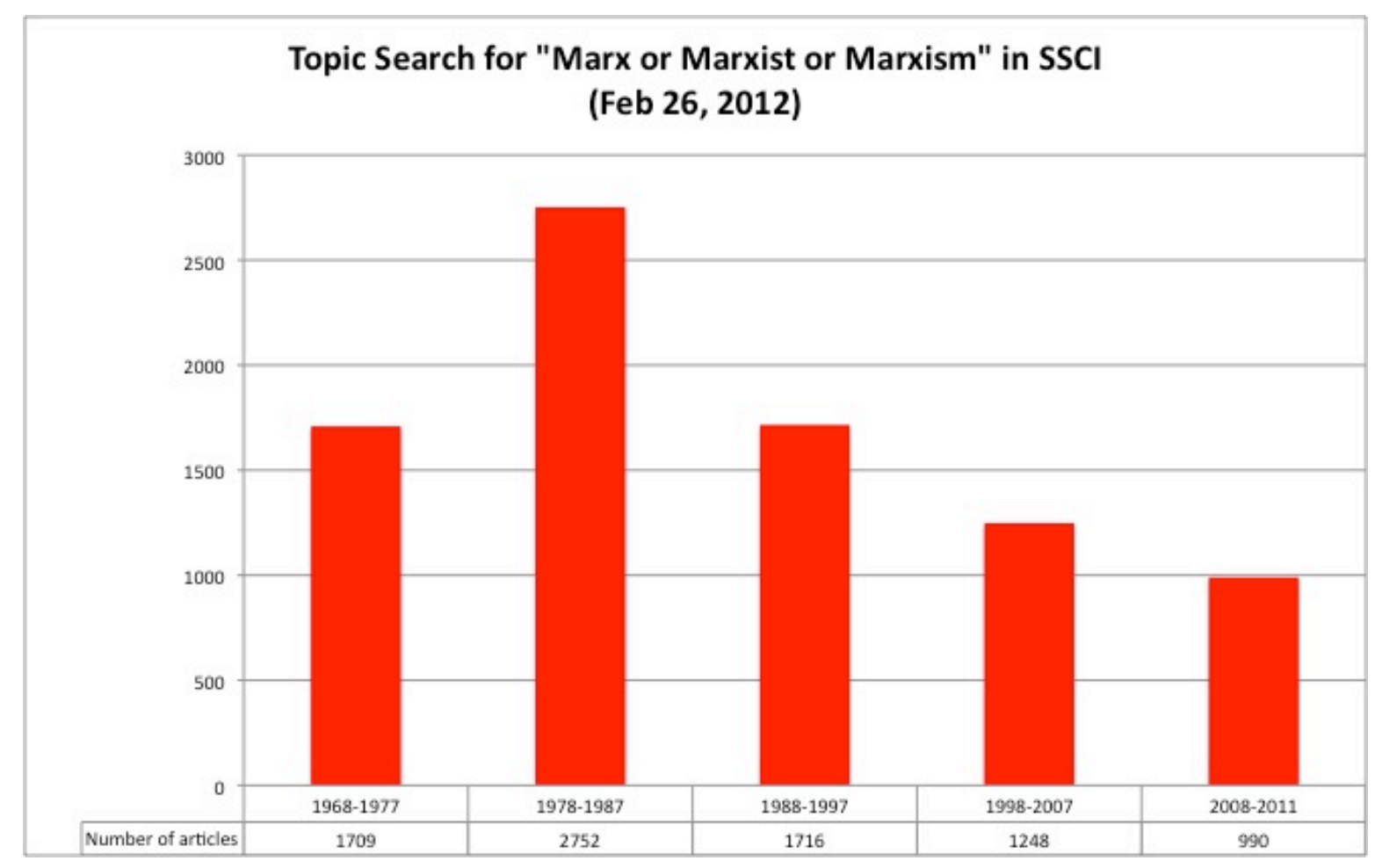

Figure 1: Articles published about Marx and Marxism that are listed in the Social Sciences Citation Index

Figure 1 shows that there was a relatively large academic article output about Marx in the period 1978-1987 (2752). Given that the number of articles published increases historically, interest in the period 1968-1977 also seems to have been high. One can observe a clear contraction of the output about articles focusing on Marx in the periods 1988-1997 (1716) and 1998-2007 (1248). Given the earlier increase of published articles, this contraction is even more pronounced. This period has also been the time of the intensification of neoliberalism, the commodification of everything (including public service communication in many countries), and a strong turn towards postmodernism and culturalism in the social sciences. One can see that the annual average number of articles published about Marxism in the period 2008-2011 (247.5) has increased in comparisons to the 
periods 1988-2007 (125 per year) and 1988-1997 (172 per year). This circumstance is an empirical indicator for a renewed interest in Marx and Marxism in the social sciences most likely an effect of the new capitalist crisis. The question is whether and how this interest can be sustained and materialized in institutional transformations.

Due to the rising income gap between the rich and the poor, widespread precarious labour, and the new global capitalist crisis, neoliberalism is no longer seen as common sense. The dark side of capitalism, with its rising levels of class conflict, is now recognized worldwide. Eagleton (2011) notes that never has a thinker been so travestied as Marx and demonstrates that the core of Marx's work runs contrary to common prejudices about his work. But since the start of the global capitalist crisis in 2008, a considerable scholarly interest in the works of Marx has taken root. Moreover, Žižek (2010) argues that the recent world economic crisis has resulted in a renewed interest in the Marxian critique of political economy.

Communism is not a condition in a distant future, it is rather present in the desires for alternatives expressed in struggles against the poverty in resources, ownership, wealth, literacy, food, housing, social security, self-determination, equality, participation, expression, healthcare, access, etc. caused by a system of global stratification that benefits some at the expense of many. It exists wherever people resist capitalism and create autonomous spaces. Communism is "not a state of affairs which is to be established, an ideal to which reality [will] have to adjust itself", but rather "the real movement which abolishes the present state of things" (Marx and Engels 1844, 57). It is a revolution of the propertyless, by those who do not own the economy, politics, culture, nature, themselves, their bodies, their minds, their knowledge, technology, etc. Communism needs spaces for materializing itself as a movement. The contemporary names of these spaces are not Facebook, YouTube or Twitter, but rather Tahrir Square, Syntagma Square, Puerta del Sol, Plaça Catalunya, and Zuccotti Park. The context of contemporary struggles is the large-scale colonization of the world by capitalism. A different world is necessary, but whether it can be created is uncertain and only determined by the outcome of struggles.

The capitalist crisis and the resulting struggles against the poverty of everything are the context for this special issue. We have set ourselves the aim to contribute with this issue to the discussion about the relevance of Marx for analyzing communication and knowledge in contemporary capitalism.

Robert McChesney $(2007,235 f$, fn 35$)$ has accurately noted that while Marx has been studied by communication scholars, "no one has read Marx systematically to tease out the notion of communication in its varied manifestations". He also notes that he can imagine that Marx had things to say on communication that are of considerable importance. The task of this special issue is to contribute to overcoming this lack of systematic reading of Marx on communication and media.

The articles in this issue, especially in the variety of topics grounded in Marxist theory and Marx's works, makes clear that Baudrillard was wrong to claim that "the Marxist theory of production is irredeemable partial, and cannot be generalized" to culture and the media and in also incorrect to insist that "the theory of production (the dialectical chaining of contradictions linked to the development of productive forces) is strictly homogenous with its object - material production - and is non-transferable, as a postulate or theoretical framework, to contents that were never given for it in the first place" (Baudrillard 1981, 214). Marshall McLuhan (1964/2001, 41) was wrong when he argued that Marx and his followers did not "understand the dynamics of the new media of communication". The special issue of tripleC on "Marx is Back: The Importance of Marxist Theory and Research for Critical Communication Studies Today" demonstrates the enormous importance of Marx's theory for Critical Communication Studies today. If one wants to critically study communication and to use that research for social change, then the work of Marx provides an essential building block. Moreover, the articles maintain that to critically examine communication we need to engage with the analysis and critique of capitalism, class, exploitation and with practical struggles for emancipation.

Our Call for Papers asked these questions:

* What is Marxist Media and Communication Studies? Why is it needed today? What are the main assumptions, legacies, tasks, methods and categories of Marxist Media and Communication Studies and how do they relate to Karl Marx's theory? What are the different types of Marxist Media/Communication Studies, how do they differ, what are their commonalities?

* What is the role of Karl Marx's theory in different fields, subfields and approaches of Media and Communication Studies? How have the role, status, and importance of Marx's theory for Media and Communication Studies evolved historically, especially since the 1960s? 
* In addition to his work as a theorist and activist, Marx was a practicing journalist throughout his career. What can we learn from his journalism about the practice of journalism today, about journalism theory, journalism education and alternative media?

* What have been the structural conditions, limits and problems for conducting Marxian-inspired Media and Communication Research and for carrying out university teaching in the era of neoliberalism? What are actual or potential effects of the new capitalist crisis on these conditions?

* What is the relevance of Marxian thinking in an age of capitalist crisis for analyzing the role of media and communication in society?

* How can the Marxian notions of class, class struggle, surplus value, exploitation, commodity/commodification, alienation, globalization, labour, capitalism, militarism and war, ideology/ideology critique, fetishism, and communism best be used for analyzing, transforming and criticizing the role of media, knowledge production and communication in contemporary capitalism?

* How are media, communication, and information addressed in Marx's work?

* What are commonalities and differences between contemporary approaches in the interpretation of Marx's analyses of media, communication, knowledge, knowledge labour and technology?

* What is the role of dialectical philosophy and dialectical analysis as epistemological and methodological tools for Marxian-inspired Media and Communication Studies?

* What were central assumptions of Marx about media, communication, information, knowledge production, culture and how can these insights be used today for the critical analysis of capitalism?

* What is the relevance of Marx's work for an understanding of social media?

* Which of Marx's works can best be used today to theorize media and communication? Why and how?

* Terry Eagleton (2011) maintains that the 10 most commonly held prejudices against Marx are wrong. What prejudices against Marx can be found in Media and Communication Studies today? What have been the consequences of such prejudices? How can they best be contested? Are there continuities and/or discontinuities in prejudice against Marx in light of the new capitalist crisis?

A Marxist theory of communication should "demonstrate how communication and culture are material practices, how labor and language are mutually constituted, and how communication and information are dialectical instances of the same social activity, the social construction of meaning. Situating these tasks within a larger framework of understanding power and resistance would place communication directly into the flow of a Marxian tradition that remains alive and relevant today" (Mosco 2009, 44). A Marxist theory of communication sees communication in relation to capitalism, "placing in the foreground the analysis of capitalism, including the development of the forces and relations of production, commodification and the production of surplus value, social class divisions and struggles, contradictions and oppositional movements" (Mosco 2009, 94). Marxist Media and Communication Studies are not only relevant now, but have been so for a long time because communication has always been embedded into structures of inequality in class societies. With the rise of neoliberalism, Marxist communication theory has suffered a setback because it had become common to marginalise and discriminate against Marxist scholarship (see the contribution by Irfan Erdogan in this special issue) and to replace Marxism with postmodernism. So Marx was always relevant, but being Marxist and practicing Marxism were always difficult, in part because Marxist studies lacked a solid institutional base. What we can see today is a rising interest in Marx's work. The question is whether it will be possible to channel this interest into institutional transformations that challenge the predominant administrative character of media institutions and strengthen the institutionalization of critical studies of communication.

We can summarize the following areas of production, usage, and effects of media as they are found in Marx's works (for a detailed discussion of Marx on media communication in capitalism and explanation of a theoretical model, see: Fuchs 2010, 2011).

\section{In commodity production:}

- Specific: Media technology as rationalization technology in the media industry

- Specific: The process of capital concentration and centralization in the media sector

- Specific: The production of media capital, knowledge workers as wage labourers in media corporations

- General: Communication technologies for the spatial and temporal co-ordination of production in order to reduce constant and variable capital shares

- General: Communication technologies as means for the spatial expansion of capitalist produc- 
tion

In commodity circulation:

- Specific: Transmission technologies as means of accumulating media infrastructure capital

- Specific: Media as carriers of advertisements

- General: Communication technologies as means for reducing the circulation and turnover time of capital

- General: Media as means and outcomes of the globalization of world trade

- General: Media as means of the spatial centralization of capital

In the circulation and reception of ideas:

- Media as carriers and circulators of ideologies

In the production, circulation, and reception of alternative media:

- Alternative media that are alternatively produced, distributed, and interpreted and function as means of class struggle and means of circulation of critical ideas

\begin{tabular}{|c|c|c|c|}
\hline Circulation & Production & Circulation & Consumption \\
\hline \multirow[t]{3}{*}{$\begin{array}{l}M-C(M p \\
L)\end{array}$} & $. . P .$. & $C^{\prime}-M^{\prime}$ & \\
\hline & $\begin{array}{c}\text { Media Technology as } \\
\text { Means of Rationalization: } \\
\mathrm{s} / \mathrm{\uparrow} \uparrow\end{array}$ & & \\
\hline & $\begin{array}{c}\text { The process of capital } \\
\text { concentration and centrali- } \\
\text { zation in the realm of the } \\
\text { media }\end{array}$ & & \\
\hline \multicolumn{4}{|c|}{$\begin{array}{l}\text { Knowledge workers as wage labourers in } \\
\text { media corporations }\end{array}$} \\
\hline \multicolumn{2}{|c|}{$\begin{array}{l}\text { Media as means of inter-organizational cor- } \\
\text { porate communication and co-ordination: } v \downarrow, c \downarrow\end{array}$} & & \\
\hline \multicolumn{4}{|c|}{ Media for the spatial distribution and extension of capitalism } \\
\hline & & $\begin{array}{l}\text { Media as carriers of ad- } \\
\text { vertisements }\end{array}$ & \\
\hline & & $\begin{array}{l}\text { Transmission media as } \\
\text { forms of capital }\end{array}$ & \\
\hline & & $\begin{array}{l}\text { Media and trade globali- } \\
\text { zation }\end{array}$ & \\
\hline & & $\begin{array}{l}\text { Media and spatial cen- } \\
\text { tralization of capital }\end{array}$ & \\
\hline & & \multicolumn{2}{|c|}{$\begin{array}{l}\text { Media as carriers \& diffusion channels of } \\
\text { ideologies }\end{array}$} \\
\hline
\end{tabular}

Table 1: A systematic account of the role of media in the Marxian circuit of capital.

The model in figure 1 summarizes the connection of four aspects of the media, i.e., four roles of the media in the capitalist economy:

1) the commodity form of the media,

2) the ideological form of the media,

3) media reception, and

4) alternative media. 
It focuses on the role of the media in the production, circulation, and consumption processes of the economy, not on the relations to the political system (state, civil society, laws, etc.) and cultural institutions (education, family, religion, etc.). Capital accumulation within the media sphere takes place in both the media content sphere and the media infrastructure sphere. These two realms together form the sphere of media capital. The Marxian circuit of capital is shown for each of the two realms, which indicates that they are oriented to capital accumulation.

The commodity hypothesis can be visualized as the following processes that are shown in figure 1: vertical and horizontal integration, media concentration, media convergence, media globalization, the integration of media capital and other types of capital, the rationalization of production, the globalization of production, circulation, and trade, and intra-company communication, advertising and marketing. The production of media content and the production of media technologies are shown as two different systems. They both belong to the media industry, but create different products. Processes of vertical integration make the boundaries between the two systems fuzzy. Concentration processes and horizontal integration, which are inherent features of capital accumulation, shape each of the two spheres. Media convergence is a specific feature of media infrastructure capital. The two realms together are factors that influence the globalization of the culture industry. The realm of the economy that is shown at the bottom right of figure 1 represents capital accumulation in non-media industries and services. It is partly integrated with the media sector due to corporate integration processes. Media technologies advance the rationalization of production in this realm as well as in the media content industry. Furthermore, they advance the globalization of production, circulation, and trade. These globalization processes are also factors that, in return, promote the development of new media technologies. Media technologies are also used for intracompany communication. Rationalization, globalization, and intra-company communication are processes that aim at maximizing profits by decreasing the investment cost of capital (both constant and variable) and by advancing relative surplus value production (more production in less time). The media content industry is important for advertising and marketing commodities in the circulation process of commodities, which is at the same time the realization process of capital in which surplus value is transformed into money profit.

The ideology hypothesis is visualized in figure 1 by media content capital and its relation to recipients. Media content that creates false consciousness is considered as ideological content. Media content depends on reception. The reception hypothesis is visualized in the lower left part of figure 1. Reception is the realm wherein ideologies are reproduced and potentially challenged.

Alternative media is a sphere that challenges the capitalist media industry. The alternative media hypothesis is visualized in figure 1 by a separate domain that stands for alternative ways of organizing and producing media whose aim is to create critical content that challenges capitalism. Media content depends on reception. Five forms of reception are distinguished in the left lower left part of figure 1. Reception is the realm where ideologies are reproduced and potentially challenged. In some types and parts of media content capital, capital is accumulated by selling the audience, at a rate determined by its demographic characteristics, as a commodity to advertising clients. Dallas Smythe (1977) spoke in this context of the audience commodity. As advertising profits are not a general feature of all media capital, there is a dotted line in figure 1 that signifies the audience commodity. In recent times, recipients have increasingly become an active audience that produces content and technologies, which does not imply a democratisation of the media, but mainly a new form of exploitation of audiences and users. 


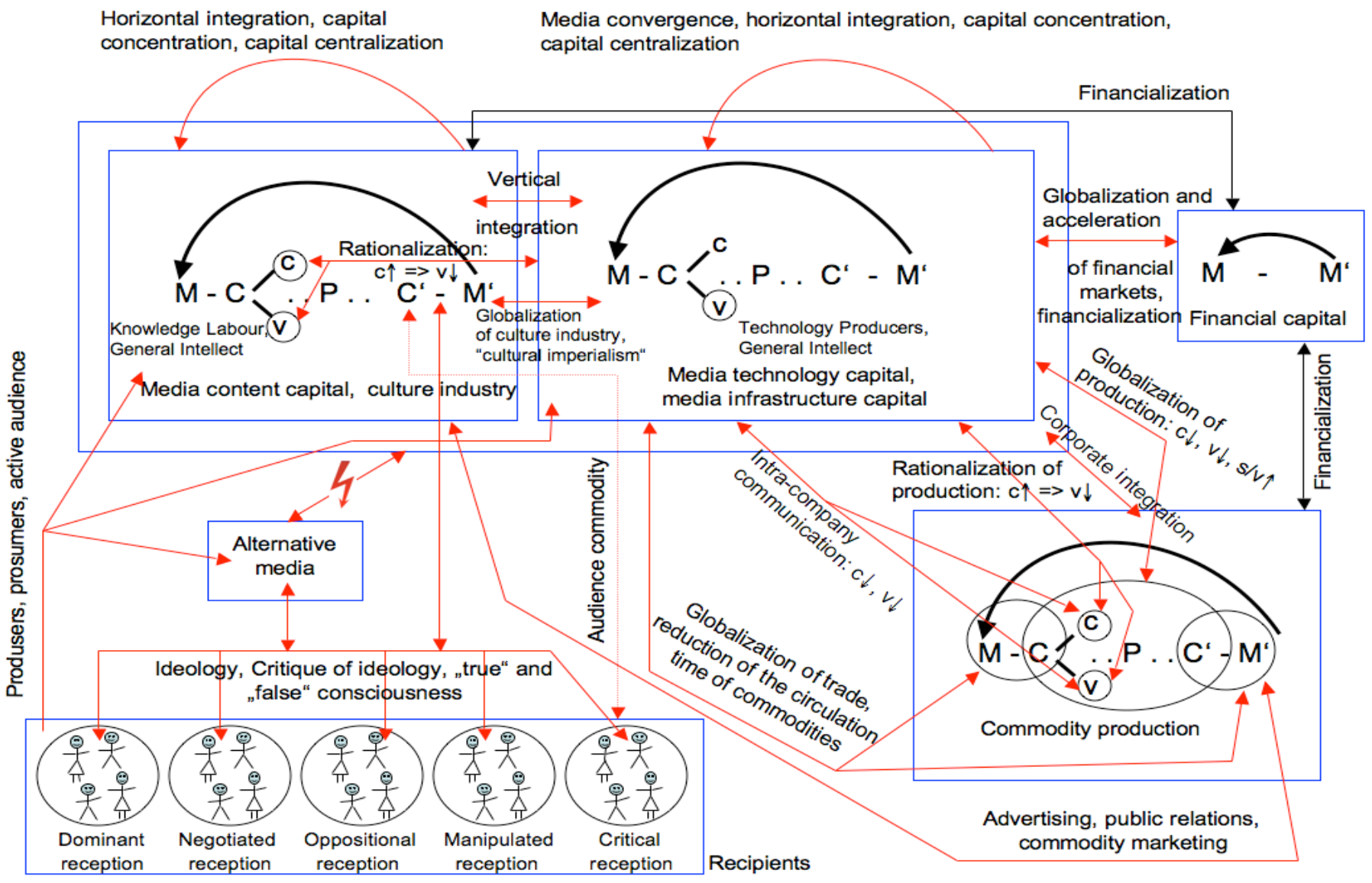

Figure 1: The processes of media production, circulation, and consumption in the capitalist economy.

The use value of media and media technologies lies primarily in their capacity to provide information, enable communication, and advance the creation of culture. In capitalist society, use value is dominated by the exchange value of products, which become commodities. When the media take on commodity form, their use value only becomes available for consumers through exchanges that accumulate money capital in the hands of capitalists. Media and technologies as concrete products represent the use value side of information and communication, whereas the monetary price of the media represents the exchange value side of information and communication. The commodity hypothesis addresses the exchange value aspect of the media. The ideology hypothesis shows how the dominance of the use value of the media by exchange value creates a role for the media in the legitimatization and reproduction of domination. The two hypotheses are connected through the contradictory double character of media as use values and as exchange values. The media as commodities are in relation to money use values that can realize their exchange value, i.e., their price, in money form. Money is an exchange value in relation to the media. It realizes its use value - i.e. that it is a general equivalent of exchange - in media commodities. Consumers are interested in the use value aspect of media and technology, whereas capitalists are interested in the exchange value aspect that helps them to accumulate money capital. The use value of media and technology only becomes available to consumers through complex processes in which capitalists exchange the commodities they control with money. This means that the use value of media and technology is only possible through the exchange value that they have in relation to money. Commodification is a basic process that underlies media and technology in capitalism. Use value and exchange value are "bilateral polar opposites" (MEW 13, 72) of media and technology in capitalist society. By the time media and technology reach consumers, they have taken on commodity form and are therefore likely to have ideological characteristics. The sphere of alternative media challenges the commodity character of the media. It aims at a reversal so that use value becomes the dominant feature of media and technology by the sublation of their exchange value. Processes of alternative reception transcend the ideological character of the media - the recipients are empowered in questioning the commodified character of the world in which they live. 
Marx's analysis of the media in capitalism visualized in figure 1 can be summarized in the form of four major dimensions. The articles in this special issue are ordered along this categorization of the role of the media in capitalism.

1) Media and commodities:

capital accumulation, media technology industry, media content industry/cultural industry, digital media industry, media and financialization, media and globalization, audience commodification, media concentration, media convergence, etc

2) Media and ideology:

media manipulation, media propaganda filters, advertising, public relations, commodity marketing, cultural imperialism, etc

3) Media reception and use:

ideological reception, critical reception, critical media use, etc

4) Alternative media:

alternative media production spheres, alternative public spheres, media and social struggles, etc

The published and submitted contributions are predominantly in the areas of media and commodification, media and ideology, and alternative media. Media reception studies are not as well represented. This means that topics like the audiences' interpretation of reality TV, popular music, soap operas, sports, movies, quiz shows, or computer games are not so important for most contemporary Marxist media and communication scholars in comparison to topics like the exploitation of free labour on the Internet, the commodification of research and education, Internet ideologies, socialist struggles about the role of the media in various countries, the marginalization and discrimination of Marxists and Marxism in Media and Communication Studies, capitalist crisis and the media, communication labour, critical journalism, the socialist open access publishing, or alternative social networking sites (which are only some of the topics addressed in this special issue). This demonstrates three key points:

* In the current situation of capitalist crisis and exploding inequality, a focus on political economy topics, class struggle issues, the role of alternatives seems to be more important than the focus on cultural studies topics (like fan culture) that can easily be accommodated into capitalist interests and do not deal with the pressing problems such as precarious living conditions and inequalities in the world.

* Classical audience studies has to a certain extent been transformed into the study of the political economy of mediated play labour and media prosumption, which is an area in which the study of production, consumption and advertising converge. Marxist Media and Communication Studies have, as this special issue shows, welcomed this convergence and related topics have become an important topic of this approach. An important implication of this development is that the classical criticism that Marxist Media and Communication Studies is not particularly interested in reception and media consumption does not hold because the issue has been taken up to a great degree with the rise of consumption becoming productive, a development that has been started by the audience commodification typical of the broadcasting area and lifted to a new dimension of analysis by the rise of Internet prosumption.

* There is a pressing need for engaging with Marx and the critique of class and capitalism in order to interpret and change the contemporary world and contemporary media. Our published papers show a deep engagement with and care about Marx's theory and it is natural that they do not align themselves with research streams that are critical of or ignore Marxist studies. They are predominantly grounded in Critical Political Economy and Critical Theory.

The 28 papers published in this special issue show the crucial relevance of Marx today for coming to grips with the world we live in, the struggles that can and should be fought, and the role of the media in capitalism, in struggles against it, and in building alternatives. It is encouraging to see that there is a growing number of scholars, who make use of Marx's works in Media and Communication Studies today. Whereas Marx was always relevant, this relevance has especially not been acknowledged in Media and Communication Studies in recent years. It was rather common to misinterpret and misunderstand Marx, which partly came also from a misreading of his works or from outright ignorance of his works. Terry Eagleton (2011) discusses ten common prejudices against Marx and Marxism and shows why Marx was right and why these prejudices are wrong. We have added to the following overview a media and communication dimension to each prejudice. This communication dimensions point towards common prejudices against Marx within Media and Communication Studies. The papers in this special issue show that these prejudices are wrong and that using Marx and Marxian concepts in Media and Communication Studies is an important and pressing task today. As a summary of the results provided by the papers in this special issue, we counter each of the anti-Marxian prejudices with a counter-claim that is grounded in the analyses 
presented in this special issue that show the importance of Marx for understanding society and the media critically.

1a) Marxist Outdatedness!

Marxism is old-fashioned and not suited for a post-industrial society.

1b) Marxist Topicality!

In order to adequately and critically understand communication in society, we need Marx.

2a) Marxist Repression!

Marxism may sound good in theory, but in practice it can only result in terror, tyranny and mass murder. The feasibility of a socialist society and socialist media are illusionary.

2b) Capitalist Repression!

Capitalism neither sounds like a good idea/theory nor does it work in practice, as the reality of large-scale inequality, global war, and environmental devestation shows. The feasibility of socialism and socialist media arises out of the crises of capitalism.

3a) Marxism $=$ Determinism!

Marx believed in deterministic laws of history and the automatic end of capitalism that would also entail the automatic end of capitalist media.

3b) Marxism = Dialectics and Complexity!

Marxian and Hegelian dialectics allow us to see the history of society and the media as being shaped by structural conditioning and open-ended struggles and a dialectic of structure and agency.

4a) Marxist Do-Goodism!

Marx had a naïve picture of humanity's goodness and ignored that humans are naturally selfish, acquisitive, aggressive and competitive. The media industry is therefore necessarily based on profit and competition; otherwise it cannot work.

4b) Capitalist Wickedness!

The logic of individualism, egoism, profit maximization, and competition has been tried and tested under neoliberal capitalism, which has also transformed the media landscape and made it more unequal.

5a) Marxist Reductionism!

Marx and Marxism reduce all cultural and political phenomena to the economy. They do not have an understanding of non-economic aspects of the media and communication.

5b) Marxist Complexity!

Contemporary developments show that the economy in capitalism is not determining, but a special system that results in the circumstance that all phenomena under capitalism, which includes all media phenomena, have class aspects and are dialectically related to class. Class is a necessary, although certainly not sufficient condition for explaining phenomena of contemporary society.

6a) Marxist Anti-Humanism!

Marx had no interests in religion and ethics and reduced consciousness to matter. He therefore paved the way for the anti-humanism of Stalin and others. Marxism cannot ground media ethics.

6b) Marxist Humanism!

Marx was a deep humanist and communism was for him practical humanism, class struggle practical ethics. His theory was deeply ethical and normative. Critical Political Economy of the Media necessarily includes a critical ethics of the media.

7a) The Outdatedness of Class!

Marxism's obsession with class is outdated. Today, the expansion of knowledge work is removing all class barriers.

7b) The Importance of Class!

High socio-economic inequality at all levels of societal organisation is indicative of the circumstance that contemporary society is first and foremost a multi-levelled class society. Knowledge work is no homogenous category, but rather a class-structured space that includes internal class relations and stratification patterns (both a manager and a precariously employed call centre agent or data entry clerk are knowledge workers) 
8a) Marxists Oppose Democracy!

Marxists favour violent revolution and oppose peaceful reform and democracy. They do not accept the important role of the media for democracy.

8b) Socialism=Democracy!

Capitalism has a history of human rights violations, structural violence, and warfare. In the realm of the media, there is a capitalist history of media support for anti-democratic goals. Marxism is a demand for peace, democracy, and democratic media. Marx in his own journalistic writings and practice struggled for free speech, and end to censorship, democratic journalism and democratic media.

9a) Marxist Dictatorship!

Marxism's logic is the logic of the party that results in the logic of the state and the installation of monstrous dictators that control, monitor, manipulate and censor the media.

9b) Capitalist Dictatorship!

Capitalism installs a monstrous economic dictatorship that controls, monitors, manipulates and censors the media by economic and ideological means. Marxism's logic is one of a well-rounded humanity fostering conditions that enable people to be active in many pursuits and includes the view that everyone can become a journalist.

10a) Non-class-oriented New Social Movements!

New social movements (feminism, environmentalism, gay rights, peace movement, youth movement, etc) have left class and Marxism behind. Struggles for alternative media are related to the new social movements, not to class struggles.

10b) Class-oriented New New Social Movements!

The new movements resulting from the current crisis (like the Occupy movement) as well as recent movements for democratic globalization are movements of movements that are bound together by deep concern for inequality and class. Contemporary struggles are class struggles that make use of a multitude of alternative media.

\section{1) Marx, the Media, Commodities, and Capital Accumulation}

Nicole Cohen analyses the exploitation of freelancers in the cultural industries. She does not share the analysis that cultural work is beyond Marxian analysis, but rather argues that one needs Marx's theory for understanding precarious cultural labour. She maintains that cultural work in capitalism should not be separated analytically from the capitalism's universal structures of exploitation and from other forms of work. Moreover, exploitation and class are at the heart of labour process theory that remains well suited for understanding labour today. Concretely, she explores the role of unpaid and precarious labour in journalism.

Mattias Ekman discusses the role of the media and communication in capitalism's primitive accumulation. The author presents three examples: 1) The Swedish media representation of the global justice movement has focused on describing single acts of actual or potential violence and has rather ignored the political goals and causes of the struggles. 2) Swedish media and politicians presented the privatization of the Swedish telecommunication company Telia as an opportunity for the public to buy "people's shares". 3) The role of dispossession and violence in the commodification of users and their labour on social networking sites like Facebook.

Eran Fisher analyses the role of alienation and exploitation in audience commodification on Facebook. Building on the work of Jhally and Smythe, he introduces the notion of audience alienation, suggesting that audiences of commercial media are not only exploited, but also do not control content and content production. The author sees Facebook asboth means of production and communication, as both a technology and a medium. Facebook would result in the exacerbation of exploitation and the mitigation of alienation, whereas commercial mass media would be based on low exploitation and high alienation.

Richard Hall and Bernd Stahl discuss how innovations in the realm of digital technology impact the university. The authors stress that in neoliberal cognitive capitalism, the university has become an important site of production of surplus value and struggles. The context of the analysis is the intensified commodification of the university from the start of the current capitalist crisis. Emerging technologies are increasingly embedded, interconnected, invisible, adaptive, personalized, and pervasive and advance commodification and fetishization in the university.

William Hebblewhite discusses Raymond Williams' paper "Means of Communication as a Means of Production". The author argues that Williams established a reductionist culturalist con- 
cept of the relation of base and superstructure and maintains that for overcoming the flaws identified in Williams' and Marx and Engels' concepts of base and superstructure, an engagement with Louis Althusser's theory is needed. Based on this theoretical framework, the author argues that the Internet is a means of production and communication and introduces the notion of promunication (production and communication).

Vincent Manzerolle and Atle Mikkola Kjøsen analyse changes in the cycle of capital accumulation that arise due to digitalization. The authors argue that personalization and ubiquitous connection are two important aspects of contemporary communicative capitalism that have impacted how the cycle of capital works. They point out that the critical analysis of capitalism and communication in capitalism should be based on the Marxian cycle of capital accumulation and that digital communication has resulted in a speed-up of the capital cycle and a facilitation of credit. They argue that the capital cycle is a communication process.

George Pleios focuses on how to conceptualize Marxist communication theory in the information society. He emphasizes that for Marx, communication in capitalism has a commodity aspect and ideological qualities and that communication is a productive force. Communication is not simply part of a superstructure, but integrated into class relations and the base. He observes this phenomenon in relation to laissez faire capitalism, monopoly capitalism, and symbolic capitalism. The convergence of leisure and work would further erase the boundaries between base and superstructure and between production and communication.

Robert Prey analyses the role of the network concept in contemporary capitalism's ideological structures. The author discusses Castells' analysis of power in the network society, highlighting the importance Castells gives to exclusion. Drawing on Boltanski and Chiapello, he stresses the problems of basing social criticism on the network metaphor, especially the lack of focus on class and exploitation. The author acknowledges the importance of networks in contemporary capitalism and argues for a combination of this approach with Marx's theory of exploitation.

Jernej Prodnik discusses the role of the commodity in critical media and communication studies. He gives an overview of how Marx discussed the notion of the commodity and points out that it is a category that has been relevant in all of Marx's works. Related concepts, such as commodity fetishism and the commodification of everything, are discussed. The author especially discusses the role of the commodity in Dallas Smythe's works and Autonomous Marxism and criticizes contemporary criticisms of Smythe's, especially the points made by Brett Caraway.

Jens Schröter examines the idea that the Internet would bring about frictionless capitalism. He stresses that the Internet became popular during the time of neoliberalism and was a technology into which hopes and ideologies of endless economic growth without crisis were projected. $\mathrm{He}$ stresses that the dot.com crisis of the early years of this century shattered this ideology. The Internet would instead be enmeshed in the contradiction between the forces and relations of production.

Andreas Wittel presents the foundations of a Marxist political economy of digital media that focuses on the concepts of labour, value, property, and struggle. The author introduces the notion of digital media as distributed media. He suggests that the means of information production have become more accessible in the digital age, whereas the capitalist class controls the means of information distribution. Wittel discusses free online labour, debates about the measurability of labour in the age of knowledge and digital media, challenges to property that began with file sharing, and struggles over the digital commons.

\section{2) Marx and Ideology Critique}

Pablo Castagno provides a Marxist framework for understanding the development of Argentina's political system and the role of media and media policies in various stages of this development. The author describes how the fascist military junta implemented neoliberalism that was later deepened by the Menem government (1989-2999). The author shows how political developments over the years influenced the role of the media in Argentina (fascist media control, neoliberal media privatization under Menen, Kirchnerismo's state-commercial nexus for establishing a national culture industry).

Irfan Erdogan analyses the role of communication in Marx's work and the role of Marx in communication studies. He conducted an empirical study of the role of Marx and Marxism in communication journals. He found that Marxian thinking has been systematically distorted and marginalized. One result is that while mainstream research tends to gently ignore Marx, alternative research traditions such as Cultural Studies tend to attack Marx and make uninformed claims. Erdogan's close study of Marx's writings shows that Marx considered communication as a crucial means of human life that has a class character in capitalism. 
Christian Fuchs gives an overview of approaches to Critical Internet Studies and points out key concepts of this field. He argues that there is an ideological difference and struggle between "Critical" Cyberculture Studies and Critical Political Economy/Critical Theory of the Internet. He discusses the role of eleven Marxian concepts for Critical Internet Studies. Marxian concepts that have been reflected in Critical Internet Studies include: dialectics, capitalism, commodification, surplus value/exploitation/alienation/class, globalization, ideology, class struggle, commons, public sphere, communism, and aesthetics.

Christian Garland and Stephen Harper reflect on the role of the critique of neoliberalism and the critique of capitalism in Media and Communication Studies: They argue that there has been a shift from a conflict between Marxism and liberalism towards a dominance of liberal pluralism and a marginalization of Marxism. The critique of capitalism would have been replaced by a critique of neoliberalism that can be accommodated with liberal pluralism. The authors outline the limits of the critique of neoliberalism with two examples: the News of the World scandal and discussions about the causes of the economic crisis.

James McGuigan reviews the debate between Critical Political Economy and Cultural Studies in light of contemporary changes in capitalism. The author stresses that by criticizing economism, Cultural Studies has often eliminated economic criticism. He points out the role of "cool" in capitalist ideology. Consumer culture would be a particularly important expression of cool capitalism. The "coolness" of communication technology is especially important. The need for a Marxist analysis of contemporary culture and the media is ascertained in order to understand their ideological and economic roles.

Brice Nixon discusses the role of dialectical thinking for a critical political economy of the media and communication. The author argues that consciousness is a crucial issue for a critical political economy. He emphasizes the role of dialectical thinking for Marx as the foundation for Marx's opposition to classical political economy. Nixon points out that a dialectical method can be incorporated into Critical Media and Communication Studies through engagement with the works of critical theorists like Georg Lukács, Herbert Marcuse, Max Horkheimer, Henri Lefèbvre, Jean-Paul Sartre, and Raymond Williams.

Michelle Rodino-Colocino analyses Sarah Palin's politics and ideology from a MarxistFeminist perspective. She argues that as part of the revival of Marxism, a revival of Marxist Feminism is needed. She maintains that there has been insufficient engagement with Marx and Marx's ideology concept in Media and Communication Studies. An engagement with Marx's ideology critique is needed today in Critical Media and Communication Studies as well as in Feminist Theory. The author shows how Palin appropriates and inverts the contents of Feminism for her own ideological political goals that serve anti-feminist purposes.

Gerald Sussman discusses the role of ideology and propaganda in the contemporary capitalist media economy. He argues that ideology and propaganda have become central productive forces and that we live in a propaganda society. The author describes the transformation of ideology under the neoliberal regime and in that part of the economy based on unpaid prosumer labour. The exploitation and surveillance of prosumers makes a Marxist theory of value crucial today. Digital media environments could also enable collective activities that resist capitalism.

\section{3) Marx and Media Use}

Brian A. Brown and Anabel Quan-Haase's contribution deals with the question of which methodology is needed for studying the digital labour and digital labour conditions of social media prosumers. The methodology for the suggested Workers' Inquiry 2.0 is grounded in Marx's questionnaire for the Workers' Inquiry and the Italian Autonomist Marxist co-research method. The authors point out with the example of research conducted about Flickr how the methodology of the Workers' Inquiry 2.0 works. They point out the importance of artefacts, communities, and produsers in the Workers' Inquiry 2.0.

Katarina Giritli Nygren and Katarina L Gidlund analyse the role of alienation in digital culture. They use Foucault's concept of pastoral power and Marx's notion of alienation. The authors draw on Foucault to describe the pastoral power of digital technology. It is a form of power that creates the illusion that digital technology allows individuality. Marx's notion of alienation is applied to the realm of digital technologies. Today traditional forms of alienation would be accompanied by digital alienation that is related to consumer culture, individualized self-expressions on platforms like Facebook, and a commodified Internet. 


\section{4) Marx, Alternative/Socialist Media and Social Struggles}

Miriyam Aouragh provides a Marxist perspective on and analysis of social media in the Arab revolutions. The author connects the notion of mediation to Marxian theory and maintains that it is a connection between base and superstructure. The revolutions are framed in terms of capitalism, imperialism, and class. The author questions the Western-liberal framing of the revolutions and social media as Orientalism and presents a model of the revolution that situates social media in an online-offline dialectic of the revolutions.

Lee Artz analyses how $21^{\text {st }}$ century socialism works in Venezuela and what the role of communication is in it. The public has the opportunity to discuss and influence all government proposals in public debates and social services were set up across the country. The author argues that Venezuela is a capitalist state with a socialist government. He analyzes the Venezuelan political economy of the media: More than $80 \%$ of the media are commercial in character. Community media and public service media oppose them. The author shows that Venezuela and Venezuelan media are in transition and have great potential for socialism.

Peter Ludes discusses the relevance of Marx's notion of a classless society. Based on a review of Marx's use of the term, he draws conclusions about the development of $20^{\text {th }}$ century capitalism. $\mathrm{He}$ argues that the establishment of alternatives requires the networking of projects that start in the here and now. Ludes suggests updating Marx's notion of a classless society by engaging with the works of Norbert Elias. This would especially require taking into account the role of communication as well as civilizing and decivilizing processes when thinking about how to establish alternatives.

Vincent Mosco argues that the crisis of capitalism has resulted in a renewed interest in Marx and that it is therefore crucial to engage thoroughly with all of his work and to pay special attention to how it can help to illuminate a blindspot of Critical Media and Communication Studies, i.e., knowledge labour and media practice. He points out the importance of the discussion of information and the means of communication in the Grundrisse as well as the significance of Marx's journalistic practice as a political calling of considerable relevance for contemporary communication students and scholars, journalists, and knowledge workers.

Wilhelm Peekhaus analyses the political economy of academic journal publishing. He demonstrates how the exploitation of the free labour of academics, monopolization and capital concentration tendencies, and high journal prices coupled with declining library budgets shapes the this industry. He interprets capitalist academic publishing as a form of primitive accumulation and points out that open access publishing can pose a viable alternative. Open access would however have today certain limits that could only be overcome by an anti-capitalist open access movement that questions the capitalist character of academic publishing.

Sebastian Sevignani analyses the alternative social networking site Diaspora* in the context of discussions about privacy in capitalism. He stresses its connections to the free software movement and describes the origins of the privacy concept and its connections to the idea of private property. The author engages with the Marxist critique of the privacy concept, which has often been ignored by Marxist thinkers, and outlines the foundations of a socialist alternative. He applies this analysis to the case of Diaspora*.

Padmaja Shaw analyses the role of Marx's works on the press for contemporary politics in India. The author discusses the relevance of three aspects of Marx's works on the press: freedom of speech and censorship, the press as a part of free trade, and the role of media in bourgeois democracies. He stresses that on the one hand, there is a broad diffusion of left-wing voices in the Indian press and that, on the other hand, censorship and repression against the Left and Left journalism reign in the insurgent Red Corridor areas. The institutionalized Left would benefit by reflecting on Marx's press politics to better respond to this situation.

This special issue shows the importance of Marxist theory for Critical Media and Communication Studies today. It makes clear that Media and Communication Studies should not just be critical in character, but that we need a Marxist Theory and Marxist Studies of Media and Communication today. The interest in and quality of this special issue as well as the large interest in other related activities in Marxist Communication Studies (as e.g. the $4^{\text {th }}$ ICTs and Society Conference: Critique, Democracy and Philosophy in $21^{\text {st }}$ Century Information Society. Towards Critical Theories of Social Media. Uppsala University. May $2^{\text {nd }}-4^{\text {th }}, 2012$. See: Fuchs 2012; and see also: http://www.icts-andsociety.net/events/uppsala2012/), especially among PhD students and younger scholars, shows that Marx is back. The deep interest in Marx's works shows the unease about capitalism and capitalist communications and the desire for alternatives. 


\section{References}

Baudrillard, Jean. 1981. For a Critique of the Political Economy of the Sign. St. Louis: Telos Press.

Eagleton Terry. 2011. Why Marx Was Right. London: Yale University Press.

Fuchs, Christian. 2012. New Marxian Times. Reflections on the $4^{\text {th }}$ ICTs and Society Conference "Critique, Democracy and Philosophy in $21^{\text {st }}$ Century Information Society. Towards Critical Theories of Social Media". tripleC - Open Access Journal for a Global Sustainable Information Society 10 (1): 114-121.

Fuchs, Christian. 2011. Foundations of Critical Media and Information Studies. New York: Routledge.

Fuchs, Christian. 2010. Grounding Critical Communication Studies: An Inquiry into the Communication Theory of Karl Marx. Journal of Communication Inquiry 34 (1): 15-41.

Marx, Karl and Friedrich Engels (MEW). Werke. Berlin: Dietz.

Marx, Karl and Friedrich Engels. 1844. The German Ideology. Amherst, NY: Prometheus Books.

Marx, Karl and Friedrich Engels. 1848/2004. The Communist Manifesto. Peterborough: Broadview.

McChesney, Robert W. (2007). Communication Revolution. Critical Junctures and the Future of Media. New York: The New Press.

McLuhan, Marshall 1964/2001. Understanding Media: The Extensions of Man. New York: Routledge.

Mosco, Vincent. 2009. The Political Economy of Communication. London: Sage. $2^{\text {nd }}$ edition.

Smythe, Dallas W. 1977. Communications: Blindspot of Western Marxism. Canadian Journal of Political and Social Theory 1 (3): $1-27$

Žižek, Slavoj. 2010. Living in the End Times. London: Verso.

\section{About the Authors/Editors}

Christian Fuchs holds the chair professorship in media and communication studies at Uppsala University's Department of Informatics and Media. He is editor of triple and author of e.g. the books "Internet and Society: Social Theory in the Information Age" (2008), "Foundations of Critical Media and Information Studies" (2011), "Social Media. A Critical Introduction" (forthcoming).

Vincent Mosco is Professor Emeritus of Sociology at Queen's University where he was Canada Research Chair in Communication and Society and head of the Department of Sociology. His most recent books include The Laboring of Communication (with Catherine McKercher, 2008), The Political Economy of Communication, second edition (2009), and Getting the Message: Communication Workers and Global Value Chains (edited with Ursula Huws and Catherine McKercher, 2010). 